\title{
First report of camel contagious ecthyma in Nigeria
}

Adeyinka Jeremy Adedeji ${ }^{1, *}$, Ahmed Abdulkadir Gamawa ${ }^{2}$, Nneka Chineze Chima ${ }^{1}$, Ahmed Isah Ahmed ${ }^{2}$, Victoria Isioma Ifende ${ }^{1}$, Jolly Amoche Adole ${ }^{1}$, Ibrahim Ahmad ${ }^{3}$, Timothy Yusufu Woma ${ }^{1}$ and Pam Dachung Luka ${ }^{1}$

\author{
${ }^{l}$ National Veterinary Research Institute, Vom, Nigeria \\ ${ }^{2}$ Animal Health Technology Department, Bauchi State College of Agriculture, Bauchi, Bauchi State, Nigeria \\ ${ }^{3}$ Directorate of Animal Health and Livestock Development, Gusau, Zamfara State, Nigeria
}

\begin{abstract}
Camel contagious ecthyma (CCE) is a viral disease of camelids that is caused by a Parapoxvirus (PPV) which is a DNA virus of the viral family: Poxviridae. Diseases affecting camels in Nigeria are scarcely reported. CCE or the laboratory detection of camel PPV (CPPV) has not been reported in Nigeria. This study investigated and described the clinical presentation of CCE and molecular detection of CPPV in Nigeria. Suspected cases of CCE were reported in a farm, live animal market and abattoir, in three different states (Bauchi, Plateau and Zamfara) in Northern Nigeria. Skin scabs, lungs, liver and intestine samples were collected. Polymerase chain reaction (PCR) was carried out using the primers which targets the RPO30 gene fragment of the genus PPV. The clinical signs observed from the suspected cases of CCE were proliferative skin lesions, papules, scabs on the lips and nares. CPPV was detected in $80.0 \%(4 / 5)$ of the samples collected by PCR. CCE was diagnosed based on clinical signs and PCR results. This is the first report of CCE in Nigeria. Further studies should be carried out to genetically characterize the CPPV circulating in Nigeria. Keywords: Camel contagious ecthyma, Nigeria, Parapoxvirus, Polymerase chain reaction.
\end{abstract}

\section{Introduction}

Camel contagious ecthyma (CCE), also called Auzdik disease or Orf is a contagious viral skin disease of camelids that occur in countries with camel husbandry system (Buchnev et al., 1987; Khalafalla et al., 2015a). CCE was first described in Kazakhstan in 1968 and subsequently in the Middle East, some parts of Asia and Africa (Buchnev et al., 1987; Oryan et al., 2017). CCE is caused by a DNA virus of the genus Parapoxvirus (PPV), subfamily Chordopoxvirinae of the family Poxviridae (Khalafalla et al., 2015a).

Presently known members of the genus PPV are Orf virus (ORFV) that affects sheep and goats, Pseudocowpoxvirus (PCPV), Bovine papular stomatitis virus (BPSV) and PPV of red deer in New Zealand (PVNZ) (Delhon et al., 2004). However, the camel PPV (CPPV) which causes CCE, reindeer parapoxvirus, musk ox and seal PPV are tentatively classified as members of the genus PPV (Khalafalla $e t$ al., 2015a).

The CPPV is not properly classified because there is scanty information on the genetic properties of the virus (Khalafalla et al., 2015b). Clinical signs of CCE include nodular skin lesions, papules and vesicles which are mostly observed around the mouth, nares, lips and eyes (Khalafalla et al., 2015a).

Morbidity rates of CCE are usually high with low mortality rates however, high mortality rates have been reported in young camel calves (Gitao, 1994;
Khalafalla, 1998). Camels are very important source of animal protein in the northern parts of Nigeria, in addition for being used for transport and other commercial activities across the northern belt bordering other West and North African states. Suspected cases of CCE were suggested to have occurred in Nigeria from pastoralist narration but the disease has not been officially reported, despite its economic importance. This study investigated and described clinical presentation and molecular detection of CPPV in suspected cases of CCE in Nigeria.

\section{Material and Methods}

\section{Study area}

The study sites were Bauchi, Jos and Gusau in Bauchi, Plateau and Zamfara states, respectively, that are located in Northern Nigeria (Fig. 1). Zamfara state shares boundary with Niger Republic at the north and bordered to the east and west by Katsina and Sokoto states. Bauchi and Plateau states are located far from the Nigerian borders where camels are usually brought into these states for slaughter, with few farms located in the northern part of Bauchi state.

The population of camels in Nigeria is estimated to be 279,802 heads (FAO, 2016). Camels are kept for traction and transport purposes by pastoralists in the northern region, and also slaughtered for meat. In addition, camels in Nigeria are kept under extensive production system which is the practice across the West African Sub-Region. 




Fig 1. Map of Nigeria showing the three states (shaded) where the cases of camel contagious ecthyma occurred.

\section{Case history and sample collection}

Suspected cases of CCE were reported in 2016 from Gusau abattoir in Zamfara state where camels were brought in for slaughter and samples were collected for laboratory investigation. A similar case was reported in a live animal market in Jos, Plateau state, where an average of 5-10 camels are brought every week for sale and slaughter. The third suspected case was reported in a camel farm outside the city of Bauchi. Farm visit revealed a herd of 15 camels (14 females and 1 male) of 2-3 years old. Clinical lesions were observed around the mouth and nares of 8 camels ( 1 male and 7 females). Affected camels were treated with oxytetracycline 20\% long acting $(1 \mathrm{ml} / 20 \mathrm{~kg}$ body weight) to control any secondary bacterial infection. Skin lesions were cleaned with disinfectants (topically) and the lesions resolved after two weeks. Skin scabs samples from live animals, and samples of lungs, liver and intestine from slaughtered animals, of all suspected cases, were collected and placed on ice and transported to the Viral Research Division, National Veterinary Research Institute, Vom, Nigeria, and stored at $-20^{\circ} \mathrm{C}$ until used. All samples were submitted to the laboratory for routine diagnosis by field Veterinarians.

The samples were homogenized using sterile mortars and pestles with the aid of sterile sand, while DNA extraction was carried out using QIAamp® DNA Mini kit (Qiagen, Hilden, Germany) following the manufacturer's instructions. PPV published primer sequences and PCR protocol were carried out as described by Torfason and Gunadóttir (2002). Positive PCR amplicons were determined by the amplification of $140 \mathrm{bp}$ product.

\section{Results and Discussion}

From the farm in Bauchi, the clinical signs observed were proliferative skin lesions, papules and scab lesions on the lips and nares (Fig. 2A, 2C, and 2D).
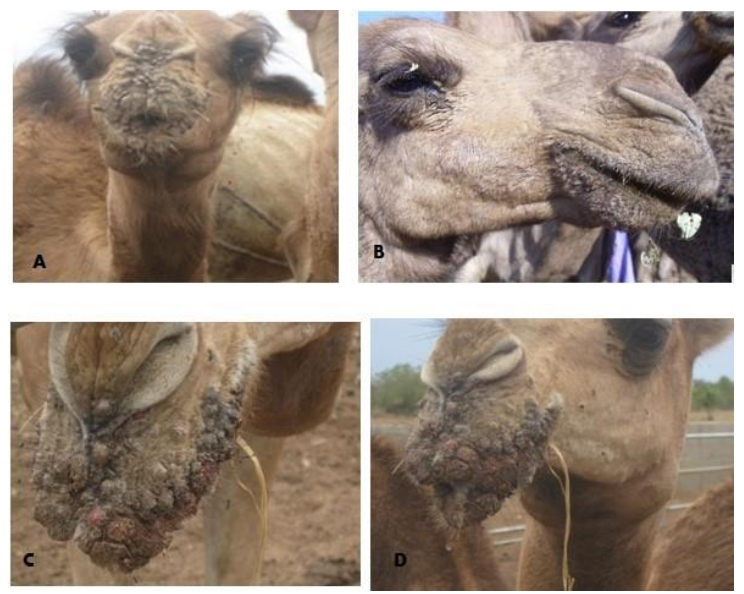

Fig. 2. Representative clinical signs of contagious ecthyma in camels observed in Nigeria. (A): Proliferative scabby skin lesion on the lips and nose of a camel in a camel farm in Bauchi, Nigeria. (B): Contagious ecthyma lesions around oral commissures in a camel in a live animal market in Jos, Nigeria. (C and D): Severe bloody and multiple scab lesions of contagious ecthyma in a camel in the Bauchi camel farm.

A morbidity of $53.3 \%(8 / 15)$ was recorded without mortality. Initial diagnosis of CCE on the farm was based on clinical signs, as samples collected were inappropriate for laboratory diagnosis. The samples from Plateau (Fig. 2B) and Zamfara states were collected from a live animal market and abattoir from camels showing signs suspected to be CCE. Clinical signs observed in the cases of CCE are presented in Table 1, which include scab lesions on the mouth, nares and neck. A total of 5 samples of skin $(\mathrm{n}=1)$, scabs $(\mathrm{n}=1)$, lungs $(\mathrm{n}=1)$, intestine $(\mathrm{n}=1)$ and liver $(\mathrm{n}=1)$ were submitted to the laboratory and analyzed (Table 1). Grossly, nodular lesions were observed on the lungs, liver and intestine during postmortem examination. CPPV was detected by specific PCR amplification of RPO132 gene segment of PPV in 80\% (4/5) of the samples (Fig. 3). Furthermore, CPPV was detected in samples of scab (1), skin (1), intestine (1) and lungs (1) (Table 1). The amplified PCR products yielded $140 \mathrm{bp}$ gene fragments for the partial RP0132 gene of the CPPV (Fig. 3).

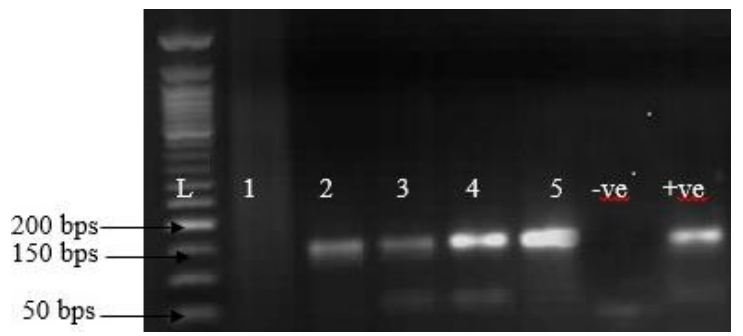

Fig. 3. Agar gel electrophoresis of PCR product of RPO132 gene of camel parapoxvirus. (Lanes 1-5): Samples collected from suspected cases. The positive samples were amplified at $140 \mathrm{bp}$ fragment. (L): DNA marker (New England BioLab®). (+ve): Positive control. (-ve): Negative control. 
Table 1. Clinical manifestation of camel contagious ecthyma and polymerase chain reaction results from samples collected in Nigeria.

\begin{tabular}{|c|c|c|c|c|}
\hline No. & $\begin{array}{l}\text { Location } \\
\text { (State) }\end{array}$ & History/Clinical signs observed & Samples collected & PCR Results \\
\hline 1 & $\begin{array}{l}\text { Bauchi } \\
\text { (Bauchi) }\end{array}$ & $\begin{array}{l}\text { Camel farm: the clinical signs observed were } \\
\text { proliferative skin lesions, papules and scab lesions on } \\
\text { the lips and nares. A morbidity of } 53.3 \%(8 / 15) \text { was } \\
\text { recorded without mortality. }\end{array}$ & Scab & NA \\
\hline 2 & $\begin{array}{l}\text { Jos } \\
\text { (Plateau) }\end{array}$ & $\begin{array}{l}8 \text { months-old male camel calf, brought to the } \\
\text { market/slaughter slab. Scab lesions around the mouth. }\end{array}$ & Scab (1) & \multirow{2}{*}{$\begin{array}{l}\text { CPPV was detected } \\
\text { in the scab sample. } \\
\text { CPPV was detected } \\
\text { in skin, intestine } \\
\text { and lungs samples. } \\
\text { The liver sample } \\
\text { was negative. }\end{array}$} \\
\hline 3 & $\begin{array}{l}\text { Gusau } \\
\text { (Zamfara) }\end{array}$ & $\begin{array}{l}\text { Two camels with proliferative scab lesions around the } \\
\text { mouth, nares and neck. The camels were brought to } \\
\text { the abattoir to be slaughtered. The initial suspicion } \\
\text { was camel pox by the field veterinarian. }\end{array}$ & $\begin{array}{l}\text { Skin (1), Intestine (1), } \\
\text { Lungs (1), Liver (1) }\end{array}$ & \\
\hline
\end{tabular}

This study provides the first clinical description and molecular detection of CPPV involving camels in Nigeria. From the literature search, the PPV infections have been reported in small ruminants but not in camels in Nigeria (Obi and Gibbs, 1978; Adedeji et al., 2017). CCE was confirmed based on clinical signs and PCR results. Camels are found mostly in the northern arid zone and Sudan savannah areas of Nigeria, where they are most adapted to the difficult climatic conditions (Nelson et al., 2015). In these rural areas of Nigeria, camels are reared for milk, meat, transport, cultivation of farmland, recreation, beauty pageants and trade (Lorusso et al., 2016).

Although some diseases of camels have been reported in Nigeria, there is, however, no reports of CCE or study on the detection of CPPV in camels. In this study, classical clinical signs of CCE were observed in camels. Clinically, CCE is similar to camel pox and camel papillomatosis, however, these diseases can be differentiated based on clinical presentation (Azwai et al., 1995; Khalafalla et al., 2005; Ayelet et al., 2013). Notwithstanding, cases of CCE have been reported to be misdiagnosed as camel pox, and co-infection of CCE and camel pox have also been reported in Ethiopia (Gelaye et al., 2016). From this study, CCE was differentiated from other viral skin diseases of camels based on clinical signs and PCR results. Skin lesions in cases of $\mathrm{CCE}$ are restricted to the face particularly around the mouth of affected animals which is why the disease is known as Auzdyk (disease around the mouth) with low mortality (Buchnev et al., 1987). Nevertheless, skin lesions in camel pox outbreaks are generalized and high mortality rates are recorded in outbreaks (Gelaye et al., 2016). The clinical signs CCE outbreak on the camel farm in Bauchi was similar to the one described in Sudan and Ethiopia by Khalafalla (1998) and Ayelet et al. (2013), respectively. No mortality recorded on the farm that might be attributed to the fact that the camels were 2-3 years of age and there was veterinary intervention. Mortality during outbreaks of CCE is usually low or varied, but it is usually recorded in camels of less than one year old (Khalafalla, 1998). CPPV was detected by PCR using specific primers which targets the RPO30 gene of the virus. The CPPV has been reported to be more closely related to the Pseudocowpox virus (PCPV), albeit CPPV has also been shown to be related to the Orf virus of sheep and goats (Oryan et al., 2017).

Interestingly, in this study, CPPV was detected from the lungs and intestine of camel samples analyzed, whereas, previous studies have reported detection of CPPV in scab samples only (Khalafalla et al., 2015b). Although PPV infections are localized to the skins, PPV has been detected in lesions on visceral organs in sheep and goats in Israel and Nigeria (Bouznach, et al., 2013; Adedeji et al., 2017). The results of this study may be attributed to the fact that camels and other livestock like cattle, sheep and goats are commonly reared together in rural households in Northern Nigeria where they share grazing land, water points and feeding troughs. Recent studies in Nigeria reported the presence of antibodies against peste des petits ruminants (PPR) and bovine viral diarrhea (BVD) in camels (Woma et al., 2014; Peter et al., 2015). These findings would suggest a possible role of camels in the epidemiology of transboundary livestock diseases in Nigeria which emphasizes the need to include them in the epidemiological studies of livestock diseases.

\section{Conclusion}

CCE was diagnosed for the first time in Nigeria based on clinical signs and PCR results. Further studies should be carried out to establish the epidemiological extend, dynamics and genetic diversity of the circulating CPPV.

\section{Acknowledgement}

We wish to acknowledge the National Veterinary Research Institute, Vom, Nigeria, where the laboratory analysis was carried out. We also acknowledge Dyek Y. Dyek and Adrian Maguda for their technical support. 


\section{Conflict of interest}

The Authors declare that there is no conflict of interest.

\section{References}

Adedeji, A.J., Maurice, N.A., Wungak, Y.S., Adole, J.A., Chima, N.C., Woma, T.Y., Chukwuedo, A.A. and Shamaki, D. 2017. Diagnosis of Orf in West African Dwarf Goats in Uyo, Akwa Ibom State, Nigeria. Afr. J. Infect. Dis. 11(2), 90-94.

Ayelet, G., Jenberie, S., Belay, A., Mohammed, A., Mola, B., Gizaw, Y. Muhie, Y., Gelaye, E., Asmare, K. and Skjerve, E. 2013. The first isolation and molecular characterization of camelpoxvirus in Ethiopia. Antiviral Res. 98, 417-422.

Azwai, S.M., Carter, S.D. and Woldehiwet, Z. 1995. Immune responses of the camel (Camelus dromedarius) to contagious ecthyma (Orf) virus infection. Vet. Microbiol. 47(1-2), 119-131.

Bouznach, A., Hahn, S., Stram, Y., Menasherov, S., Edery, N., Shicaht, N., Kenigswald, G. and Perl, S. 2013. Case Report: Contagious Ecthyma Deviations in the Anatomical Appearance of Lesions in an Outbreak in Lambs in Israel. Isr. J. Vet. Med. 68(4), 246-251.

Buchnev, K.N., Tulebaev, S.Z. and Sansyzbaev, A.B. 1987. Infectious diseases of camels in the USSR. Revue Sci. Tech. Off. Int. Epi. 6(2), 487-495.

Delhon G, Tulman ER, Afonso CL, Lu Z, de la ConchaBermejillo A, Lehmkuhl HD, Piccone ME, Kutish GF, Rock DL. Genomes of the parapoxviruses ORF virus and bovine papular stomatitis virus. $\mathbf{J}$ Virol. 2004;78:168-177.

FAO (Food and Agriculture Organization of the United Nations). $2016 . \quad$ FOOSTAT. http://www.fao.org/faostat/en/\#data/QA. Accessed on $10 / 2 / 2018$.

Gelaye, E., Achenbach, J.E., Ayelet, G., Jenberie, S., Yami , M., Grabherr, R., Loitsch, R.G., Diallo, A. and Lamien, C.E. 2016. Genetic characterization of poxviruses in Camelus dromedaries in Ethiopia 2011-2014. Antiviral Res. 134, 17-25.

Gitao, C.G. 1994. Outbreak of contagious ecthyma in camels (Camelus dromedarius) in the Turkana district of Kenya. Revue Sci. Tech. Off. Int. Epi. 13, 939-945.

Khalafalla, A.I. 1998. Epizootiology of camelpox, camel contagious ecthyma and camel papillomatosis in the Sudan. Proceedings of the Third Annual Meeting for Animal production Under Arid Conditions. United Arab Emirates University Press, 2, 115-131.

Khalafalla, A.I., Büttner, M. and Rziha, H.J. 2005.
Polymerase chain reaction (PCR) for rapid diagnosis and differentiation of para-and orthopox virus infections in camels. In: H.P.S. Makkar and G.J. Viljoen (eds). Applications of Gene Based Technologies for Improving Animal Production and Health in Developing Countries. FAO/IAEA Publications, SPRINGER, pp: 335-342.

Khalafalla, A.I., El-Sabagh, I.M., Al-Busada, K.A., AlMubarak, A.I. and Ali, Y.H. 2015a. Phylogenetic analysis of eight Sudanese camel contagious ecthyma viruses based on B2L gene sequence. Virol. J. 12, 124. doi: 10.1186/s12985-015-0348-7.

Khalafalla, A.I., Al-Busada, K.A. and El-Sabagh, I.M. 2015b. Multiple PCR for rapid diagnosis and differentiation of pox and pox-like diseases in dromedary camels. Virol. J. 12, 102 . doi: 10.1186/s12985-015-0329-x.

Lorusso, V., Wijnveld, M., Latrofa, M.S., Fajinmi, A., Majekodunmi, A.O., Dogo, A.G., Igweh, A.C., Otranto, D., Jongejan, F., Welburn, S.C. and Picozzi, K. 2016. Canine and ovine tick-borne pathogens in camels, Nigeria. Vet. Parasitol. 228, 90-92.

Nelson, K.S., Bwala, D.A. and Nuhu, E.J. 2015. The Dromedary Camel; A Review on the Aspects of History, Physical Description, Adaptations, Behavior/Lifecycle, Diet, Reproduction, Uses, Genetics and Diseases. Nig. Vet. J. 36(4), 12991317.

Obi, T.U. and Gibbs, E.P. 1978. Orf in sheep and goats in Nigeria. Trop. Anim. Health Prod. 10, 233-235.

Oryan, A., Mosadeghhesari, M., Zibaee, S. and Mohammadi, A. 2017. Identification and phylogenetic analysis of contagious ecthyma virus from camels (Camelusdromedarius) in Iran. Onderstepoort. J. Vet. Res. 84(1), e1-e5. doi: 10.4102/ojvr.v84i1.1257.

Peter, I.D., El-Yuguda, A.D., Mshelia, G.D. and Dawurung, J.S. 2015. Detection of bovine viral diarrhea virus antibodies in camels (Camelus dromedarius) in Maiduguri, Nigeria. Sok. J. Vet. Sci. 13(3), 49-52.

Torfason, E.G. and Gunadóttir, S. 2002. Polymerase chain reactin for laboratory diagnosis of Orf virus infections. J. Clin. Virol. 24(1-2), 79-84.

Woma, T.Y., Kalla, D.J., Ekong, P.S., Ularamu, H.G., Chollom, S.C., Lamurde, II, Bajehson, D.B., Tom, N.D., Aaron, G.B., Shamaki, D., Bailey, D., Diallo, A. and Quan, M. 2014. Serological evidence of camel exposure to peste des petits ruminants virus (PPRV) in Nigeria. Trop. Anim. Health Prod. 47, 603-606. 